\title{
Nutrition Intervention as Service Learning: Silliman University's Indigenous Food Security in Philippine High Risk Calamity Areas
}

\author{
Michele Aclaro-Naranjo ${ }^{1, *}$, Alvyn Klein Alpuerto Mana-ay, Jin Honculada-Genove, and \\ Ruth Ann Sumili Entea \\ HE-ND Department, Silliman University, Hibbard Ave, Dumaguete City, 1 Hibbard Ave, \\ Dumaguete, 6200 Negros Oriental, Philippines
}

\begin{abstract}
Hunger is a major concern in times of disaster and it can result in malnutrition. Hence, food becomes the most important immediate need in times of disaster. As a result of climate change, the Philippines is one of the most disaster-prone areas in the world. Disaster preparedness is a challenge that everyone in the Philippines must address. A collaborative effort between Silliman University Nutrition and Dietetics Departmentthrough Service-Learning and the local government units became a means to reduce social inequalities in disastrous situations. The goal of this project was to immerse students in a community to prepare selected community members to cope with emergency nutritional needs, and to teach them food preservation techniques using available indigenous foods. The program carried out lectures on nutrition education and calamity awareness. These included seminars, workshops, cooking demonstrations and backyard gardening, food preservation for consumption during calamities was the major activity of this project. The community members were taught how to nourish themselves within $48 \mathrm{~h}$ during disasters using the skills they learned. This project contributed to students' whole person education through service-learning by developing in them the values of empathy, concern to others, volunteerism, and strong community engagement with local government units.
\end{abstract}

Keywords: Calamity, disaster, food preservation, food security, indigenous foods, nutrition intervention, service-learning.

\section{Introduction}

In the Philippines, Service-Learning (SL) has become popular because it fulfils one of the higher education institutions' (HEI) commitments which is on community engagement [1]. A higher education institution such as Silliman University understands that it is part of a larger community and that, according to Silliman University President Dr. Ben S. Malayang III [2], "It is not an isolate as it were, devoid of responsibility to society." This characteristic of Silliman education is further manifested in what former Vice President for Finance and Administration Prof. Cleonico Y. Fontelo [3] said that a good life is one that

${ }^{*}$ Corresponding author: micheleanaranjo@su.edu.ph 
inspires and makes a difference in the greater community it serves. As one author noted, "the community is served best if its individual component work as an interdependent whole rather than a series of unrelated parts" [4] and SL as a teaching strategy provides that opportunity for students, faculty, and staff of an academic institution to better collaborate with the larger community [5].

SL in its most basic form is a method of teaching, learning, and reflecting. It can be transformed and expanded to become a comprehensive tool for community development and educational enrichment. SL can be used to address the root causes of social problems by using structured opportunities that are intentionally designed to promote students' learning and development as well as to enhance their critical thinking skills [6].

\section{Philippine nutrition situation}

Disasters in the Philippines are a perennial reality due to the archipelago's location in the "Pacific Ring of Fire" and its proximity to the abounding waters of the Pacific Ocean. The two most recent major disasters--the 7.2 magnitude earthquake in Bohol Province, and the super typhoon Yolanda (International name: Haiyan) - that affected central Philippine provinces cost thousands of lives of Filipinos and billions in infrastructure. Due to these occurrences, the whole nation foresees calamities as one of the major challenges that should be prioritized. This has been a huge challenge to the country, as these disasters cause great risks to the livelihood, nutrition, and health condition of many communities. Hunger is a major concern in times of disasters, and it can result in malnutrition. Hence, food has become the most important necessity.

\section{Service-learning: A pedagogical movement}

Amongst the academe, SL has been deemed as a major pedagogical movement, from primary and secondary school levels to higher education, and to education for health professionals. Providing structured reciprocal experiences to academic institutions, SL has become a way of responding to identified community needs. It is emphasized by Marcus et al. [7] that there is a collaborative need for students and the academia, as its moral obligation, to reduce social inequalities in real-world situations.

In Silliman University, Central Philippines, students of the Nutrition and Dietetics program were able to relate to the mothers of malnourished pre-schoolers who came primarily from households where most of the male heads were engaged in fishing and/or construction work. It was an SL project in collaboration with government agencies which cooperated without reluctance and engaged in activities to help combat malnutrition. Community engagement did not only benefit the community but also the students and faculty by enhancing the implementation of academic programs and learning goals, thereby widening the scope of influence and ultimately improving the quality of education in specific disciplines. A well-organized, cooperative, and distinct SL program within educational institutions leads to new ways of thinking and articulating people's role in society. HEIs are also able to fulfil one of their commitments to their partner communities through institutionalized SL programs [1].

In Dumaguete City, Philippines, Silliman University's Home Economics-Nutrition \& Dietetics Department (SU HE-ND) has long established a strong collaboration with the local government through the City's Nutrition Office. The advocacy and promotion of good nutrition in various communities through the University's Marina Mission Clinic-a community partnership between Silliman University and the Municipality of Dauin in Negros Oriental--has been sustained through seminars and workshops on "Responsive 
Calamity Preparedness in Nutrition and Food Security." With local government officials, and health and community workers, Silliman University has been actively involved, for many years, in calamity response and preparedness in the province of Negros Oriental and other neighbouring regions.

In this SL framework, the objective of organizing and mobilizing selected stakeholders in typhoon-risk communities is to define the immediate and efficient response to a climate change emergency. In such community-based leadership roles, there is also strength in the commitment of SU HE-ND's faculty and students to help prepare the community to deal with emergency nutritional needs through the transfer of knowledge and techniques of food preservation and utilization of indigenous foods. The framework of having community service as an integral part of the course can be conceptualized as a pedagogical model which connects meaningful community service experiences with the academic learning course. By effectively designing the students' assignment, the faculty can enable the students to capture their learning from this community service experience. This allows the boosting of the students' communication, collaboration, and leadership skills [8].

Together with the project participants who were considered as lead implementers-local government partner agencies and their personnel, and the beneficiaries of the SL project themselves - BS Nutrition and Dietetics (BSND) students and faculty members of selected Nutrition and Dietetics (ND) professional courses (i.e. subjects) became the lead implementers. Other stakeholders who served as partner agencies were the City Nutrition Office and Local Barangay Councils of the selected high-risk areas of Dumaguete City, and the Barangay Nutrition Workers (BNWs) and community leaders who had been equipped to handle calamity response. The ultimate beneficiaries were members of typhoon-risk communities who had also been trained to respond to emergency nutritional needs in disastrous times.

This project is anchored on the premise that in order for SL programs to flourish, schools must understand that a robust base of support is necessary which includes building a strong relationship with partners in the community. SL practitioners and school administrators view its local government partners and other non-government partner organizations as "co-teachers" in the teaching and learning process [9]. Moreover, SL becomes effective when there are constantly open lines of communication [10] and when rapport is established, as such would guarantee an effective collaboration within partners in the community [11].

The integration of academic study with community service is the primary component of this educational model. It is an attempt to connect critical theory with the learning process using the learning-by-doing approach such as the use of interaction. This contributes to a deeper level of learning which results not only from the combination of theoretical knowledge with practical knowledge but also from the activation of emotions. Both concepts of science shops and SL can highlight that it is not enough that universities simply remain as producers of knowledge, merely educating students who then become potential researchers and decision-makers of the future; instead, universities should take the responsibility of engaging with local communities through answering their research questions and contributing to the solution of various local problems [12].

\section{Nutrition interventions}

This SL program on calamity preparedness and food preservation started with the concept based on the 2014 Nutrition Month theme, "Calamity preparedness: Hunger and malnutrition prevention" (Kalamidadpaghandaan: gutom at malnutrisyonagapan). The thrust was to support nutrition interventions that responded to the needs of Filipinos in times of calamity. Subsequently, the project envisioned to develop a sense of responsibility 
among the nutritionally at-risk group and people in high-risk areas, so they can deal with their needs in times of calamity [13].

Calamities are among the major events that affect the nutritional status of Filipinos since food security is challenged by unforeseen emergencies and overwhelming changes in food supply and demand. To address such situations, the HE-ND Department developed a plan that could help the community prepare for calamity emergencies using indigenous resources and methods. The scope of the project largely integrated nutrition-sensitive activities and calamity preparedness as these two are a pressing concern for the whole nation due to inevitable conditions caused by climate change. In particular, the program sought to increase community awareness about food security preparedness including the process of sustaining needs before, during, and after a disaster. The program also aimed to enable the participants to recognize the abundance of local food resources and products which are highly rich in nutrients. Such foods are beneficial as they can be harnessed to maintain people's well-being during calamities. The project consisted of activities such as lectures and cooking demonstrations on the utilization of endogenous local crops (e.g. camote, banana and malunggay) through a variety of product development methods. Wilk [14] posits that flavour and feeding are both learned and shared values which are culturally shaped. From this point of view, endogenous local crops are utilized for high acceptability of the product developed, are prepared by stakeholders, and are used as emergency food reserve.

\section{Major activities}

Funded by the United Board for Christian Higher Education in Asia (UBCHEA) through a small grant, the full-blown project started in 2015. As shown in Dumaguete City's Local Disaster Risk Reduction and Management Center (LDRRMC) hazard map, the city is considered medium to low-risk hazard. The program targeted to reach the Barangays that are at risk during typhoons and floods such as Buñao, Batinguel, Camanjac, Candau-ay, Balugo, Junob, Cadawinonan, Bajumpandan and Motong. In addition, the program also included the community of San Jose, Tacloban City which was the epic centerof the typhoon, Haiyan.

For the actual engagement, one way to organize people to be nutritionally-prepared during calamities is by training BNWs and other community leaders on local food security and calamity preparedness and response. As the main stakeholders, they are to radiate nutrition services with the locals, more specifically to the mothers with malnourished children who were the project beneficiaries.

From the HE-ND perspective, there were six major activities in this SU-SL which were as follows: i) courtesy call with government officials; ii) Nutrition in Emergency Workshops; iii) emergency food reserve through food preservation and cooking demonstrations; iv) backyard gardening; v) focus group discussions (FGDs); and vi) a culminating activity.

\section{Steps to deeper collaboration}

The courtesy call involved arranging a meeting with the barangay officials in their respective barangays where the SUND team presented the project's intended goal, objectives, and timeline of activities that were all meant to raise awareness of the inherent risks of typhoon-related calamities and to ultimately earn the participants' support and commitment in the implementation of the project. 
The Nutrition in Emergencies activity aimed to promote awareness on nutrition-related problems in the locality and some possible solutions especially duringa disaster or calamity. Food preservation and cooking demonstration activities offered training for the participants on the preparation of banana and sweet potato chips as "emergency food". This activity intended to equip the family with skills in preparing ready-to-consume calorie and nutrientdense foods during calamities.

The backyard and containerized gardening provided an opportunity for the community to apply methods of planting crops and vegetables in their own home backyard. An FGD enabled the participants to share their reflections on and evaluation of the SL program. At the end of the major project's implementationperiod, a culminating activity concluded the entire program.

Internal partners were the following: Silliman University President, the liaison person for the United Board and the Office of the Instruction whose comments and guidance in drafting the proposal significantly contributed to the realization of this project; Silliman University Institute of Service-Learning which provided the ND faculty members and students the knowledge and skills in dealing with partner communities and shared financial assistance during the trip to Tacloban City.

External partners included the Dumaguete City Barangay Officials who helped the group in facilitating communication with the participants and who also allowed SUND to use some of their rooms, day care centers for the SL, and their kitchen for the cooking demonstrations; Dumaguete City Nutrition Office which, through its Barangay Nutrition Workers, willingly agreed to volunteer in organizing the participants in all sessions of SUND SL; Negros Oriental Department of Agriculture who shared their knowledge on the basic concepts of planting and also shared some seedlings; Region 8-Bureau of Fisheries and Aquatic Resources (BFAR) that allowed the team to use some of their utensils for the cooking demonstration; Office of the city mayor of Tacloban that allowed the SUND to conduct an SL in San Jose, Tacloban (one of the hardest-hit areas during the onslaught of Typhoon Haiyan); and Tacloban City Agriculturist Office which was in-charge of the venue and of organizing the target participants/community in Barangay Payapay, San Jose.

\section{Challenges encountered}

A key factor which was often viewed as the most obvious and the largest obstacle challenging both higher education institutions and their community partners in the conduct of SL activities was the university's academic semester time frame which may not be congruent with those of their partner organizations [15]. However, a study showed that over $70 \%$ of partner organizations of schools with SL activities reported that "the benefits of working with student volunteers far outweighed the problems and costs." [5]

The greatest challenge encountered was during the cooking demonstration that was done either without kitchen on the community's open field or without proper kitchen utensils and facilities, and without enough space and water supply. Nevertheless, the activity was carried out successfully as the participants were enthusiastic to learn how to cook indigenous food preserves and their respective community leaders were very supportive.

The presence of infants and young children hindered the mothers from fully participating in some of the activities as they divided the mothers' attention; some of the community halls/areas where the SL activities were held are located near the main road, so a considerable amount of noise hindered learning and the addressing of participants' needs; another challenge encountered was the participants' lack of availability since not all of them became easily available, especially when SL activities came in conflict with other schedules such as school activities or other commitments of community members. 
Apparently, the materials, especially the seedlings used were limited due to supply problems.

One thing that was surprising was the potential discipline that some community leaders planned to enforce on their members if they failed to attend SL activities.One form of discipline was withholding the small cash grants for indigent families. It was surprising to know that the Tacloban City participants mentioned that the SUND were one of the Filipino volunteers who went to their area and invited the whole community to join the SL activity. Previously, there were only a few of them who were selected to attend a disaster seminar or training, and not all benefited from the said advocacy. All participants expressed their heartfelt gratitude for the SL they experienced. While the SUND Team felt the sting that had marked the lives of many homeless families, it was also a dream come true for themhaving been able to learn, serve, and touch lives.

Reflecting on the SL experience in Tacloban City, Leyte, a student wrote: "I believe one of the greatest challenges tackled during the implementation of the project was the language between us and the people of Tacloban since both share two very different languages-Waray and Bisaya. At first, it was extremely difficult that we needed the representatives from the fisheries and aquatic resources bureau to translate Waray into Tagalog for us to be able to communicate properly. What surprised us the most was that at the end, despite the language barrier, the fisherfolk of the barangay learned a lot of things and appreciated all our efforts to be able to educate them on calamity preparedness."

"Since the project was implemented across only a few barangays in Dumaguete City and one in Tacloban, widening the scope of influence would surely bring a greater impact especially to those people in calamity-stricken areas. With the proper communication between Local Government Units and the school and the proper organization of the project in more areas, the project could change more lives and educate more and more people especially in Tacloban and its neighboring towns. It can be sustained through monitoring the barangays that were visited and comparing its progress to what their original situation was."

\section{Success with collaboration}

One clear example of a highly successful SL project in collaboration with local governments is the Local Government Website Initiative in the State of Michigan in the United States [15]. This SL project, which involved more than 275 students and six faculty members across five universities on the part of the academe, and three state government agencies and nearly a hundred local government units on the part of the State of Michigan, sought the development of operational and sustainable websites for online government services. On the project's success, Michigan's Governor gave an accolade stating that "This effort serves as a shining example of teamwork and the great things that can happen when people work together." The governor further said that not only is the project able to benefit the citizens of the State of Michigan, it is also a great experience for the students involved in this service-learning activity [15].

Overall, the HE-ND students were overwhelmed, knowing that they gave their best as they performed the transfer of knowledge beyond the four walls of their classrooms. Moreover, by their willingness to gain additional practical knowledge about preparedness in times of disaster, the participants showed remarkable enthusiasm and cooperation in such theory-application activities. This exposure then made HE-ND students realize the personal and intangible rewards of learning and knowledge-sharing as evident in their note-worthy SL journal entries such as the following: "Despite the hardship and tiresome preparation, we did it and it all paid off when you see them laugh and smile. I've realized that we are there to reach out to help and make them happy in some simple way." Another one added: 
"I was very delighted by this activity because as a student, it helps me to be prepared in my future profession." On the other hand, most of them were eagerly anticipating other community exposures: "I am really thankful that I was able to have this experience and I am really looking forward to be with these people again in the community."

The students believed that they had successfully achieved their objectives in this activity to a certain extent. This excerpt from a student reflection is a testament to such success: "...there were even some mothers who verbalized that they can make a business or livelihood out of the indigenous products that we taught them." And with this determination that they have observed from the participants, they believed that the activity was truly sustainable: "The activity can be sustained by monitoring the community . . . so that whatever was learned cannot be wasted; but instead, be applied for the rest of their lives."

On the other hand, the Nutrition Action Officer of Dumaguete City Mrs. Lourdes Taburaza noted that this SL project of Silliman University HE-ND Department had indeed been very timely and relevant as the Philippine government had been giving priority attention to calamity prone areas where disasters most likely happen. The actual knowledge and inputs given by the HE-ND SL project trained the participants to be ready during a calamity. Besides, this nutrition emergency workshop is important most especially among at-risk groups where recovery response feeding prevents further incidence of malnutrition. The FGD was also a strategic activity to validate the community's state of preparedness when a calamity happens.

\section{Conclusion}

All these are true-to-life stories from the experiences that the local partners and participants shared with Silliman University's HE-ND Department students and faculty-manifesting how communities cope when in a calamity strikes. Their future response can also lead to a great improvement in their lives. Through this SL program funded by the UBCHEA, Silliman University's HE-ND Department has accomplished its commitment to respond to the call of the University President, Dr. Ben S. Malayang III, who has taken notice that "with disasters and calamities as the 'new normal,' the need to integrate adaptive solutions to development interventions is a must." As a disaster risk reduction strategy, "Nutrition Intervention as Service Learning: Silliman University's Indigenous Food Security in Philippine High Risk Calamity Areas" is then both commendable and worth replicating not only in other parts of the Negros Island Region (NIR) but also in the whole Philippines, an archipelago in the ASEAN region.

\section{References}

1. E.G. Oracion. Employing typologies of learning for a holistic evaluation of servicelearning students. A paper presented at the Multi-Institutional Service-Learning Forum on "Ethical Concerns and Human Protection Issues in Service-Learning" Asian Christian Faculty Fellowship-Philippines, Inc. (ACFFPI), in partnership with the University's Institute of Service-Learning, Dumaguete City, Philippines. (Silliman University, Philipines, 2014). Article in press.

2. Malayang, B. What $d r$. hibbard might have seen. [Online] from https://su.edu.ph/183what-dr-hibbard-might-have-seen/ [Accessed on 17 January 2017].

3. Fontelo, C. What awaits you? [Online] from https://su.edu.ph/1243-what-awaits-you/ (2014). [ Accessed on 17 January 2017]. 
4. Sharp, M. Local governments and school: A community-oriented approach. [Online] from https://icma.org/documents/local-governments-and-schools-community-orientedapproach (2008). [ Accessed on 17 January 2017].

5. Redlawsk, D.P., Wilson, N. Local political involvement and service learning. [Online] from http://citeseerx.ist.psu.edu/viewdoc/download?doi=10.1.1.597.1212\&rep=rep1\&type= pdf (2006). [ Accessed on 17 January 2017].

6. A. English. Changing the world from classrooms to communities: Designing and disseminating a service-learning curriculum for teaching in a formal education setting. [Thesis] Honors College Capstone Experience Thesis Projects. Department Political Sciences, Western Kentucky University, Kentucky, U.S.A. (2012). p. 3. https://digitalcommons.wku.edu/stu hon theses/342/

7. M.T. Marcus, W.C. Taylor, M.D. Hormann, T. Walker, D. Carroll. Nursing Outlook, 59,1:47-54(2011). doi:10.1016/j.outlook.2010.10.001.

https://www.ncbi.nlm.nih.gov/pubmed/21256362

8. University of Minnesota. Benefits of service-learning. Center for community engagedlearning [Online] from http://www.servicelearning.umn.edu/info/benefits.html (2017). [Accessed on 15 January 2017]

9. G. Robinson. Creating sustainable service learning programs: Lessons learned from the horizons project, 1997-2000. Washington, DC.: American Association of Community Colleges. [Online] from https://www.csus.edu/indiv/n/nancem/pdffiles/sustainability.pdf (2000). [Accessed on 20 January 2017]

10. Science Education Research Center, Carleton College. How to use service-learning [Online] from https://serc.carleton.edu/introgeo/service/howto.html (n.d.). [Accessed on 20 December 2017]

11. M. Beadle, Y. Needham, M. Dearing. Nurse Educ. Pract. 12,6:352-355(2012). Doi:10.1016/j.nepr.2012.04.005 https://www.ncbi.nlm.nih.gov/pubmed/22634061

12. B. Bodorkós, G. Pataki. J. Clean. Prod. 17,12:1123-1131(2009). https://www.sciencedirect.com/science/article/pii/S0959652609000730

13. National Nutrition Council. Nutrition month theme: approved! [Online] From http://www.nnc.gov.ph/regional-offices/region-iii-central-luzon/124-2014-nutritionmonth-theme-approved (2014). [Accessed on 9 December 2017]

14. R. Wilk. Physiol Behav. 107,4:471-475(2012). doi: 10.1016/j.physbeh.2012.04.023 https://www.ncbi.nlm.nih.gov/pubmed/22579934

15. S. Poindexter, P. Arnold, O. Christopher. MJCSL. 15:56-67(2009). https:/quod.lib.umich.edu/cgi/p/pod/dod-idx/service-learning-from-a-distancepartnering-multiple.pdf? $=$ mjcsl;idno $=3239521.0015 .205$; format $=$ pdf 